症例

$$
\begin{gathered}
\text { 同時性三重複癌（食道，胃，尿管）の } 1 \text { 例 } \\
\text { 九州大学第 } 1 \text { 外科, 千早病院外科* } \\
\text { 園 田 } \begin{array}{llll}
\text { 幸 } & \text { 生 } & \text { 佐 藤 } & \text { 裕 中 村 賢二郎 } \\
\text { 三 好 } & \text { 晃* }^{*} \text { 田 中 雅 夫 }
\end{array}
\end{gathered}
$$

食道・胃重複癌の術前精査に際して偶然に発見した右尿管癌を含む同時性三重複癌の

1 例を経験した．症例は62歳男性. 胃㵋瘍の経過観察のため行った内視鏡検查で食道癌 と胃癌の重複癌と診断された。術前の腹部超音波検査で右水腎症を認め, 尿細胞診の結 果右尿管癌を伴っていることが判明した．同時性三重複癌の診断のもとに，食道癌に対 し内視鏡的粘膜切除術を行った12日後に，胃全摘術（第 2 群リンパ節郭清）兼右腎尿管 摘出術を施行した。組織像は各々, 扁平上皮癌 (食道), 高分化腺癌 (胃), 移行上皮癌 (尿管)であった．消化器系重複癌の増加に伴い，他科領域癌の重複をも念頭に置いた臨 床的対応が重要である。

索引用語：同時性三重複癌（食道，胃，尿管）

\section{緒言}

近年, 社会の高齢化や癌治療成績の進歩, 診断技術 の向上により重複癌の報告が増加傾向にあるが，消化 器系と汹尿器系の組み合わせの重複癌の報告は比較的 稀である.今回われわれは食道癌, 胃癌に加え, 術前 検査にて偶然に発見された尿管癌を含む“同時性三重 複瘦”の 1 症例を経験したので，文献的考察を加え報 告する.

$$
\text { 症例 }
$$

患者：62歳, 男性.

主訴：なし（胃謴瘍の経過観察中）。

既往歴：21歳, 虫垂切除。54歳, 胃濽瘍（以後内科 的治療).

生活歴：日本酒 1 日 2 合 $\times 40$ 年間.タバコ 40 本 $\times 40$ 年間.

家族歴：特記すべきことなし.

現病歴：1995年12月25日, 胃謴場の経過観察のため 定期的に行っている内視鏡検查で, 下部食道 ( $\mathrm{Ei}$ 領域) に不整粘膜像を, 胃体中部後壁に IIa +IIc 様の病変を 指摘された。さらに術前スクリーニング検查として 行った腹部超音波検查で, 右水腎症を認めたため, 2 月15日精查加療目的にて当科に入院した。

入院時現症：胸腹部理学所見に特記すべき事項はな

1997年 7 月 24 日受付 1997 年10月 8 日採用
かった. 表在リンパ節の腫大も認めなかった。

入院時検查所見：血液学的検查に異常は認めなかっ た. 生化学的検査において, BUN 8mg/dl, Cr 1.6mg/ $\mathrm{dl}$, クレアチニンクリアランス $46.6 \mathrm{ml} / \mathrm{min}$ と軽度の 腎機能低下を認めたか，腫瘍マーカーは CEA, SCC, CA19-9共に正常範囲内であった。

食道造影検查（図 1)：食道透視で食道 $\mathrm{Ei}$ 領域に浅 い不整形の潰瘍性病変を認めた。生検で扁平上皮癌と 診断された.

胃透視検査 (図 2)：胃体中部後壁に，周堤様隆起を 伴ってその中央に浅い不整形のバリウム斑を呈する潰 瘍性病変認め, IIa +IIc 樣胃癌と診断した (生検では低

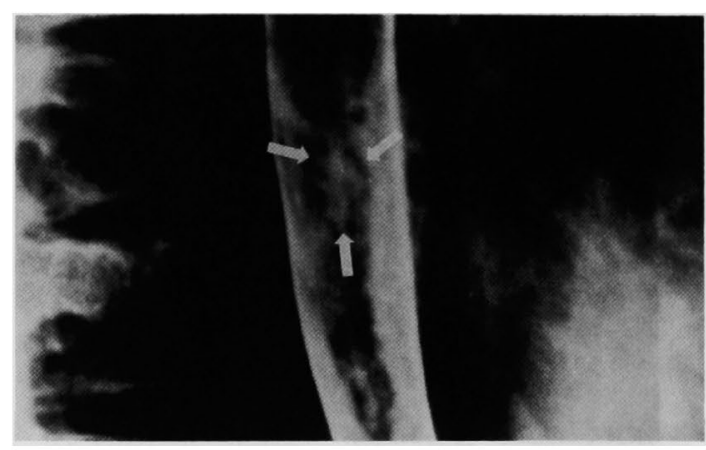

図 1 食道造影検查：下部食道（Ei 領域）に不整粘膜 像を認めた（矢印）。 
分化型腺癌であった).

泌尿器系検査（図 3 )：逆行性尿管造影にて右尿管中 部に不整形陰影欠損像を認め，その上流に尿管の拡張 像を伴っていた，尿細胞診において移行上皮癌が検出 された。

CT 検査：肝転移，リンパ節転移の所見は認めな かった。

以上の検査結果より，食道癌，胃癌，右尿管癌の同 時性三重複癌と診断した。

手術：食道超音波内視鏡では，食道粘膜の層構造の

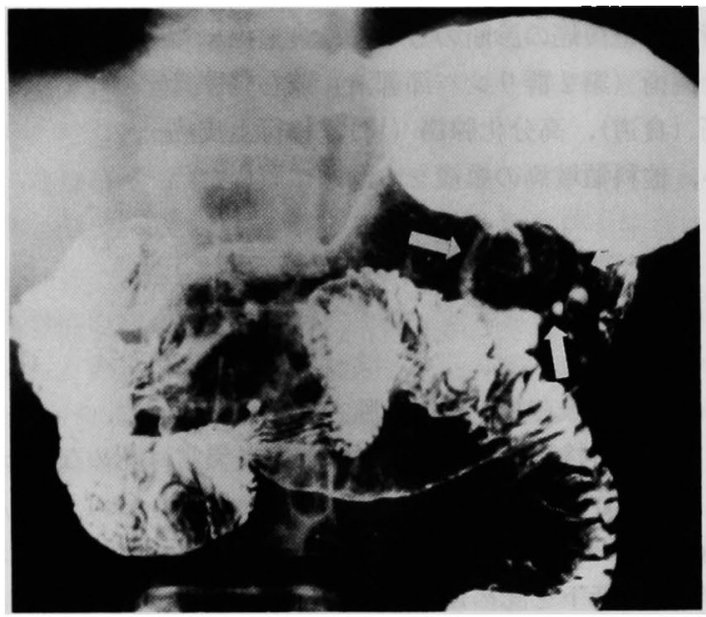

図 2 胃造影検査：胃体中部後壁に周提様隆起を伴う IIa +IIc 病変を認めた（矢印）。

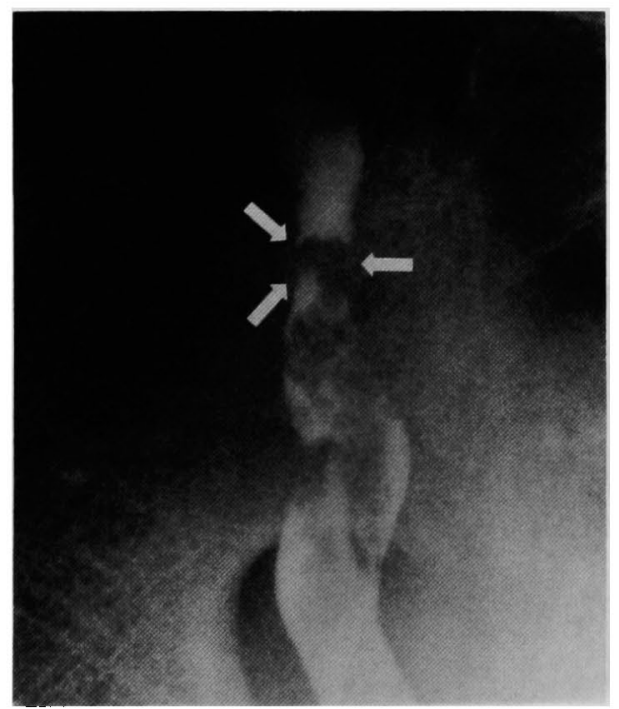

図 3 逆行性尿管造影：上流尿管の抎張像と下部尿管 内に不整形陰影欠損像を認めた（矢印）。
変化や周辺リンパ節の腫大を認めないため早期癌と診 断した。軽度ながら腎機能低下を伴っていたので過大 侵襲を避けるために，まず食道癌に対して 2 回にわけ て,内視鏡的粘膜切除術 (EMR) を施行した。病理組 織検査で完全切除を確認した後，3月 6 日(EMR 後12 日目）に胃全摘術（第2 群リンパ節郭清）および右腎 尿管摘出術を施行した。

病理所見：EMRによって切除した食道病変は図 4 に示した。病理組織診断では粘膜内癌であり切除断端 も陰性であった，胃病変は粘膜集中像を伴う不整形の 陥凹性病変を 2 力所に認め(図 5 ), 病理組織診断で高 分化型腺癌で深達度は固有筋層に留まっていたが，第 1 群のリンパ節 (4Sa 番) に転移を認めた。尿管の病変 は, 有茎性の径 $7 \mathrm{~mm}$ の乳頭状の腫瘤であり（図 6 ),

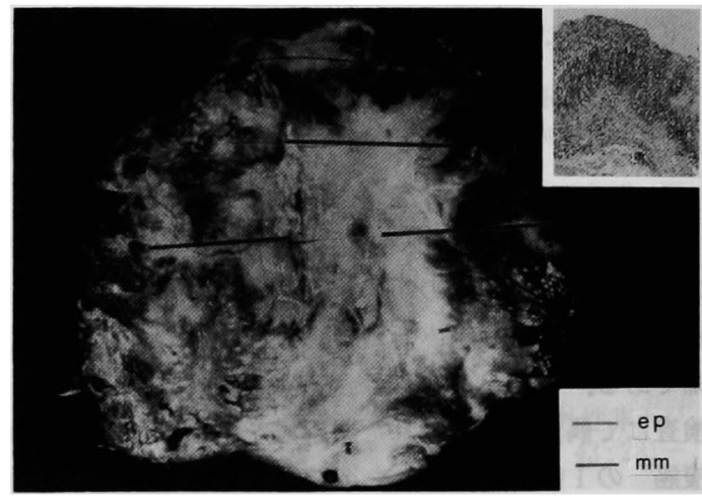

図 4 食道切除標本（EMR）：切り出し切片の検索に よる癌の深達度は ep (淡線)， $\mathrm{mm}$ (濃線)であった。 扦入ルーぺ像：扁平上皮癌 $(\mathrm{HE}, \times 40)$

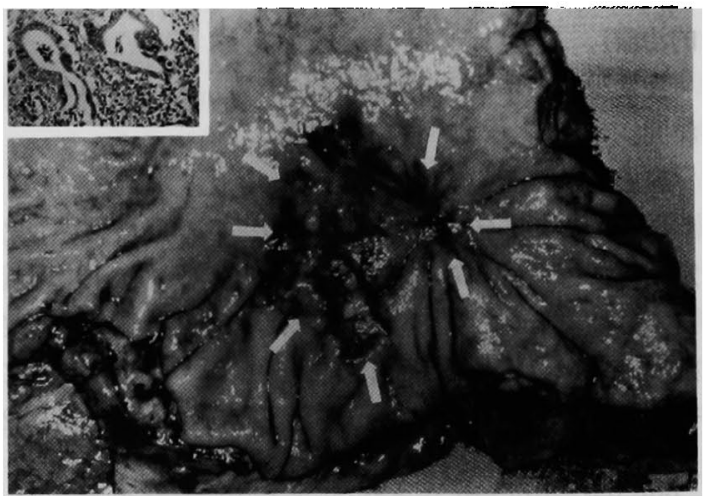

図 5 胃切除標本：粘膜集中像を伴う不整形の陥山性 病変を 2 力所に認めた.

挿入ルーぺ像：高分化腺癌 $(\mathrm{HE}, \times 100)$ 


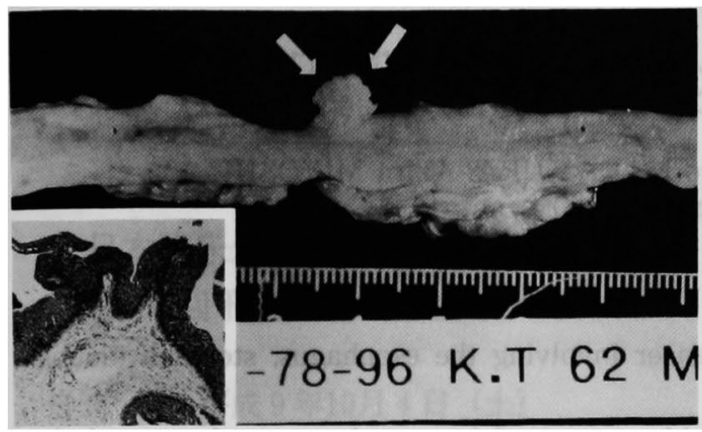

图 6 尿管切除栖本：有荎性の径 $10 \mathrm{~mm}$ の乳頭状の 腫溜であった。

捚入ルーぺ像：移行上皮癌（HE, × 40)

病理組織診断では非浸潤性で乳頭状発育を呈した移行 上皮癌であった。

術啳経過：腎機能に大きな変動なく経過し術後36日 目に退院となった．退院後経口抗癌阂の内服のみで外 来経過観察中てあるが, 術後16力月現在まで再発なく 経過している.

\section{考 察}

重複䆗の判定としては Warren \& Gates の基準"が 一般的である. 即ち，(1)各腫瘍が明確な覀性像を持つ こと, (2)各腫場の性質, 種類, 部位等が異なった別個 の腫䨗であること，(3)一方が他方の転移でないこと， といった 3 つの条件を満たした場合，重複癌と判定さ れる．本症例においてはその判定基準を十分に満たす ものであり，また診断が同時期であることより同時性 三重複癌と診断した.

泌尿器系癌を含む重複癌の点からみると, 泌尿器系 癌自体が比較的高龄者に好発することにより，他葴器 にも癌が重複する確率が高く，重複癌全体に占める泌 尿器系重複癌の比率は高いとされている゙が，三重複

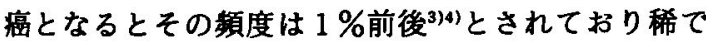
ある.さらには泌尿器系のなかでも尿管癌を含む三重 複䍃はほとんど報告がなく，特に本症例のような消化 器系重複癌（食道，胃）と尿管癌といった組み合わせ の同時性の三重複癌の報告はわれわれが調え得た限り では認めず，極めて稀な病態と考えられた。

一方，本邦において食道癌および胃癌を基準におい た合併他臓器癌の分布では, その過半数が消化器系湶 てあり，泌尿器系癌は極めて稀にしか認めえなかつ $た^{5 / 6)}$. 実際，臨床の場で消化器癌の患者を診る場合，

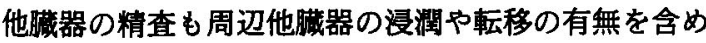
て消化器系を中心に行うことが一般的である.しかし
ながら, 剖検例の検討であるが泌尿器領域を基準にお いた合併他荿器癌の分布をみると，食道・胃を含む消 化器系癌が頻度としては最も多いものであり ${ }^{3)}$, 観点 を変えることにより組み合わせ藏器の重複にかなりの 差が生じてくるものと考えられる.本症例においては, 術前のスクリーニング検查で水腎症を認めたことが契 機となって第三の癌として尿管癌が発見され，極めて 幸運な症例であったともいえる。

従来, 単発癌に比へてて予後不良とされてきた多重複 癌も早期発見され根治手術がなしえた症例では，比較 的良好な予後が期待される7). 多重複癌の外科的治療 に関しては，個々の患者においてその予後を一義的に 規定する癌の治療を優先するというのが一般的に認め られた臨床的対応である. しかしながら外科的に切除

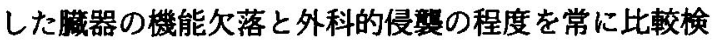
討しながら個々の症例に対する外科的適応を決すべき と考える。

今後重複癌症例の増加に伴い, 稀な組み合わせと考 えられる多重複癌の出現も十分に予想されるので, 臨 床の場においては他科領域（他臟器）を含めた多重複 癌の存在を念頭に置き，十分な臨床的対応を行ってい くことが肝要である.

\section{結 語}

食道癌，胃癌，尿管癌という稀な組み合わせの同時 性三重複癌の 1 例を経験したので報告した。

なお本症例は第58回日本臨床外科学会総会 (1996年10月, 京都）にて発表した。

\section{文献}

1) Warren $S$, Gates $O$ : Multiple primary malignant tumors: A survey of the literature and a stastical study. Am J Cancer 16: 1358-1414, 1932

2）高橋 悟, 杉本雅幸, 箫原 充他：膀腃癌における 多重癌の臨床的検討. 日泌尿会誌 $83 ； 1118-$ 1123, 1992

3）岩道孝一郎, 杉本雅幸, 赤座英之他：泌尿器科領域 における重複癌。最新医 $40: 1704-1710,1985$

4) 柿崎 弘, 阿部寞子, 营野 理他：尿路性器癌を含 む多重複癌100例の検討. 日泌尿会誌 $83: 1841-$ 1846, 1992

5）佐藤 博, 磯野可一, 小野田昌一：食道と他臟器 癌. 最新医 $40: 1629-1633,1985$

6) 高木國夫, 渡辺 進, 高橋知之他: 胃癌と他臟器 癌. 最新医 $40: 1634-1641,1985$

7）竹内仁司, 小長英二, 岩瀬浩典他：一期的切除が可 能てあった三重複癌の 1 例. 瘦の臨 38 ： 925932, 1992 


\title{
A CASE OF SYNCHRONOUS TRIPLE CANCER INVOLVING THE ESOPHAGUS, STOMACH AND URETER
}

\author{
Yukio SONODA, Hiroshi SATOH, Kenjiro NAKAMURA, Akira MIYOSHI* \\ and Masao TANAKA \\ Department of Surgery I, Faculty of Medicine, Kyushu University \\ *Department of Surgery, Chihaya Hospital
}

We herein report a case of synchronous triple cancer involving the esophagus, stomach (double cancer), and ureter.

A 62-year-old man was diagnosed as having double cancer of hte esophagus and stomach by endoscopy performed for a follow-up study of gastric ulcer. Preoperative screening abdominal ultrasonography showed a right hydronephrosis, and a cytological examination of the urine revealed malignant transitional cells. A preoperative diagnosis of synchronus triple cancer (esophagus, stomach and ureter) was thus made. After an endoscopic mucosal resection for the early esophageal cancer, a radical total gastrectomy and a right nephroureterectomy were successfully carried out. Postoperative pathological examination revealed that the esophageal cancer was squamous cell carcinoma, the gastric cancer was well-differentiated adenocarcinoma, and the ureteral cancer was transitional cell carcinoma. Whenever we encounter cancers of the gastrointestinal tract including hepato-biliary-pancreatic system the possible coexistance of multiple malignancies occurring in other organs must be kept in mind. 